\title{
Phenotypic plasticity of Paracentrotus lividus (Echinodermata: Echinoidea) in a lagoonal environment
}

\author{
Catherine Fernandez ${ }^{1,2, *}$, Charles-François Boudouresque ${ }^{2}$
}

${ }^{1}$ CEVAREN and CRITT Corse Technologie, Université de Corse, BP 52, F-20250 Corte, France

${ }^{2}$ UMR-DIMAR 3, BP 901, Faculté des Sciences de Luminy, F-13288 Marseilles Cedex 9, France

\begin{abstract}
A.BSTRACT. The relative sizes of the different somatic and gonad components of the sea urchin Paracentrotus lividus (Lamarck) were studied at 2 sites in a coastal Mediterranean lagoon to demonstrate the phenotypic plasticity of this species to environmental conditions. Sampling sites varied with regard to substrate type, sea urchin population density, and, in particular, food resource. Results indicate that when food resources [beds of Cymodocea nodosa (Ucria) Asherson] are not limiting, P. lividus exhibits high repletion (relative weight of the gut and its content), gonad and test indices. When food is limited, test and gonad indices decline and the relative size of the feeding apparatus increases. These variations may be related to changes in the allocation of energy so as to maximise the acquisition of food. These results show that $P$. lividus is capable of changing its morphology in response to available food resources and demonstrate the high degree of plasticity of this species.
\end{abstract}

KEY WORDS: Echinoidea Paracentrotus lividus - Mediterranean - Lagoon - Phenotypic plasticity Energy allocation

\section{INTRODUCTION}

Populations of sea urchins often present different morphological and physiological characteristics according to the environment in which they develop (Ebert 1996). When populations are not genetically isolated, the variations observed can be attributed to the differences in environmental conditions: they are responses to environmental pressure. These variations can affect a range of parameters such as growth rate, maximum size, reproduction and body morphology (Régis 1978, Lumingas 1994, Lozano et al. 1995, Turon et al. 1995). Thus, sea urchins can adapt their physiological parameters in response to temperature (Moore 1935), hydrodynamics (Edwards \& Ebert 1991), environmental quality (Delmas \& Régis 1984) and especially the quality and quantity of available food (Lawrence \& Lane 1982).

Paracentrotus lividus (Lamarck) is a widespread species on Atlantic and Mediterranean coasts, and it plays

\footnotetext{
•E-mail:egel@univ-corse.fr
}

a determining role in the development of benthic macrophyte communities (Verlaque 1987). This species is also intensively fished for commercial purposes in several countries. For this reason, there has been a considerable number of studies on its nutrition and growth in the open sea. Conversely, there has been little research on its morphological adaptations to its habitats.

The aim of this study was to examine the relative allocation of resources to the different components of the sea urchin Paracentrotus lividus in a lagoonal environment at 2 sites where population density and trophic resources are very different. The description of these parameters will offer insight into the biology of the species in the lagoonal environment and provide evidence of the urchin's phenotypic plasticity in response to its food resource.

\section{MATERIALS AND METHODS}

Sampling sites. Specimens of Paracentrotus lividus were collected at 2 stations in the Urbinu lagoon. This 


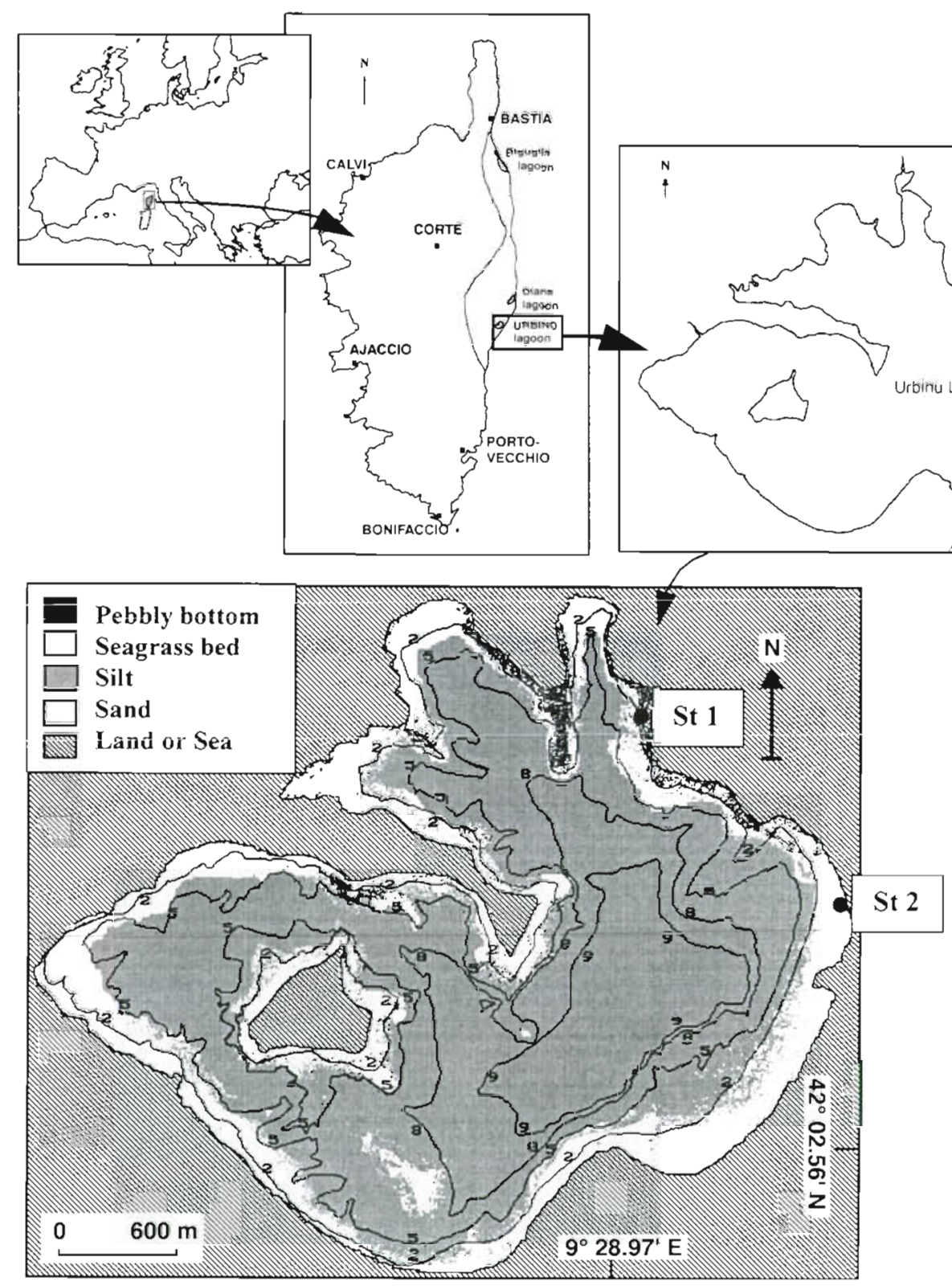

Fig. 1. Urbinu lagoon (France, Mediterranean) and sampling stations. St 1: pebble station; St 2: seagrass bed station

lagoon, located on the east coast of Corsica (Mediterranean, France; $42^{\circ} 03^{\prime} \mathrm{N}, 9^{\circ} 28^{\prime} \mathrm{E}$; Fig. 1 ), is of tectonic origin with an area of 750 ha and a maximum depth of $9 \mathrm{~m}$. There is a small opening leading to the sea in this lagoon (Fig. 1) and some water exchanges occur between the 2 environments (less than $6 \%$ of the total volume of the lagoon per month). The temperature in this lagoon varies from $7^{\circ} \mathrm{C}$ in winter to $29^{\circ} \mathrm{C}$ in summer (Fig. 2). Stn 1, the 'pebble station', is situated to the northwest of the lagoon on pebble beaches. Stn 2, the 'seagrass bed station', is located in the seagrass beds near the mouth of the lagoon (Fig. 1). These 2 stations differ mainly in the availability of food, type of bottom, and sea urchin population density. The other conditions (depth, hydrodynamics, temperature and salinity) are similar at both stations. The bottom at the pebble station consists of a 0.5 to $6 \mathrm{~cm}$ layer of pebbles that is very poorly occupied by macrophytes. Sea urchins at this station consume mostly plant detritus and, to a lesser degree, dead animals and micro-phytobenthos (Fernandez 1990); the nutritional value of plant detritus (particulary the seagrass derived detritus) is low (Mazzella et al. 1992). This station supports a high density of sea urchins (mean \pm confidence interval: $27.0 \pm 3.6$ ind. $\mathrm{m}^{-2}$; Fernandez 1990) and is favourable to recruitment and to the presence of small sea urchins (presence of shelters and crustose coralline algae) (Fig. 3). The seagrass bed station is character- 
ized by a sandy bottom colonized by Cymodocea nodosa (seagrass) with a density of 750 shoots $\mathrm{m}^{-2}$ and provides an abundant supply of food. C. nodosa is a preferred food species for $P$. lividus (Traer 1980). At this station, the sea urchin population density is low $10.7 \pm$ 0.4 ind $\mathrm{m}^{-2}$ ) and composed principally of adult sea urchins. Sampling was done on a trimestrial basis (August 1991, November 1991, February 1992 and May 1992) at both stations for 2 size classes. Ten individuals of each size class (31 to $40 \mathrm{~mm}$ in diameter, 11 to $24 \mathrm{~g}$ wet weight; and 41 to $50 \mathrm{~mm}$ in diameter, 22 to $44 \mathrm{~g}$ wet weight), were sampled in the seagrass bed and pebble bottom stations. In order to verify pertinency of the results obtained using this time scale, monthly sampling, which covered more than 1 yr (May 1991 to July 1992), was also carried out, but only at 1 site (seagrass bed) and for 1 size class (41 to $50 \mathrm{~mm}$ ).

Laboratory methods. For each sample, the sea urchins were measured and weighed. They were then dissected into various components: gonads, gut (without gut contents), test (without Aristotle's lantern), Aristotle's lantern and gut contents. Each component was drained on filter paper and weighed to the nearest $0.1 \mathrm{mg}$. For each component, half was weighed and dried at $70^{\circ} \mathrm{C}$ to constant weight for estimation of water content. For Aristotle's lantern and gut contents, the whole amount was dried. The relation between com- ponents was then calculated. Two relationship types were used

(1) $\mathrm{Cl}_{1}$ (Component Index) is the ratio between the dry weight of the component (DWC) expressed in $\mathrm{mg}$ and the test diameter cubed $\left(d^{3}\right)$ expressed in $\mathrm{cm}^{3}: \mathrm{Cl}_{1}$ $\left(\mathrm{mg} \mathrm{cm}^{-3}\right)=\mathrm{DWC} / \mathrm{d}^{3}$ [this relationship is derived from the index of repletion in Nédélec (1983)].

(2) $\mathrm{CI}_{2}$ is the relationship between the wet weight of the component (WWC) and the total wet weight of the sea urchin (TWW) in mg (this ratio expresses a percentage $): \mathrm{CI}_{2}(\%)=\mathrm{WWC} \cdot 100 / \mathrm{TWW}$ [this relation was proposed by Lawrence et al. (1965)].

If relationship (1) appears to be more precise because it eliminates variations in measurement due to
Fig. 3. Paracentrotus lividus. Example of relative size frequency distributions of sea urchins in pebbly bottom and in seagrass bed stations (in June 1990)

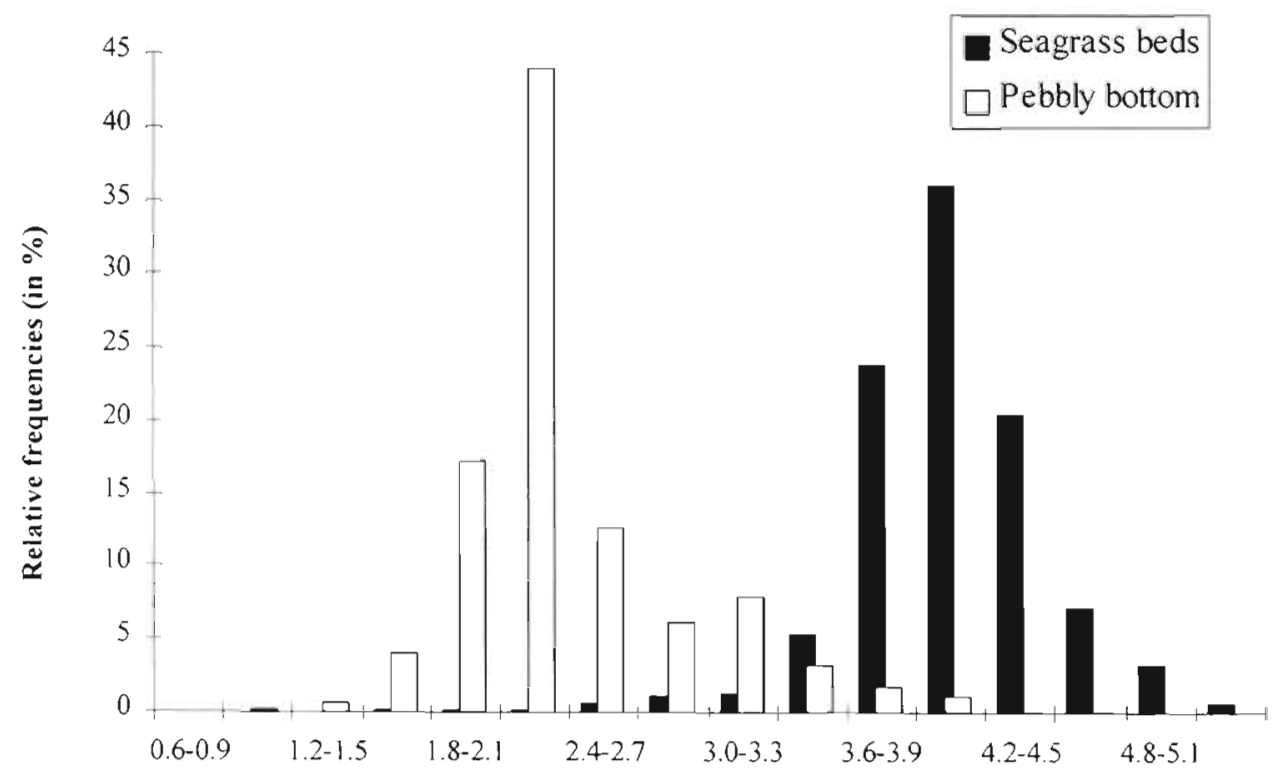

Class size (in $\mathrm{cm}$ ) 
the water content of the sea urchins, relationship (2) enables us to determine the proportion of each component in living sea urchins. In this study, relationship (1) was adopted for the repletion and gonad indices (repletion index: relative weight of the gut and its content) while relationship (2) was used for the gut, test and lantern indices.

Data were processed by 1 -way analysis of variance (ANOVA; for analyses over the annual cycle, monthly samples) or 2-way ANOVA (for analysis of size and station factors at given months, trimestrial samples) followed by Tukey's HSD (Zar 1984). No interaction between the 2 factors was observed with our data. Previously, normality and homoscedasticity were verified by Kolmogorov-Smirnov \& Bartlett tests respectively (Zar 1984). The software Statgraphics Plus (version 1.4) for Windows was used.

\section{RESULTS}

\section{Relative size of the gonads, gut, test and lantern}

In the seagrass bed station of the Urbinu lagoon, the distribution of the different components of Paracentrotus lividus in relation to the total wet weight of the sea urchin was found to be $43.2 \pm 2.5 \%$ for the test (annual mean $\pm 95 \%$ confidence interval), $3.8 \pm 0.2 \%$ for the lantern, $2.0 \pm 0.5 \%$ for the gut, $9.0 \pm 2.9 \%$ for the gonads and $42 \pm 1.0 \%$ for residues (composed of gut content and coelomic liquid). The test is always the largest part of the body, and, of the soft parts, the gonads always possess a higher relative weight than the gut.

\section{Repletion index}

Individuals from the seagrass bed station (monthly samples) present significant seasonal variations of the repletion index (1-way ANOVA, $F=3.4, p<0.0001$ ) (Fig. 4). Two-way ANOVA carried out on size and station factors for the 4 months (trimestrial samples) of the study indicate that both factors are significant. With regard to the station factor, the repletion index is always lower for individuals from the pebble station (where trophic resources are limiting) than for those from the seagrass bed station. (station factor: $F=5.1$ to 62.5, $p<0.01$ ) (Fig. 4). The repletion index is an indication of the differences in resource availability. The lower the resource availability, the lower the repletion index. The difference between the 2 stations is also important in terms of quality: Cymodocea nodosa offers an abundant food supply for sea urchins all year round. Paracentrotus lividus behaves, in this biotope,

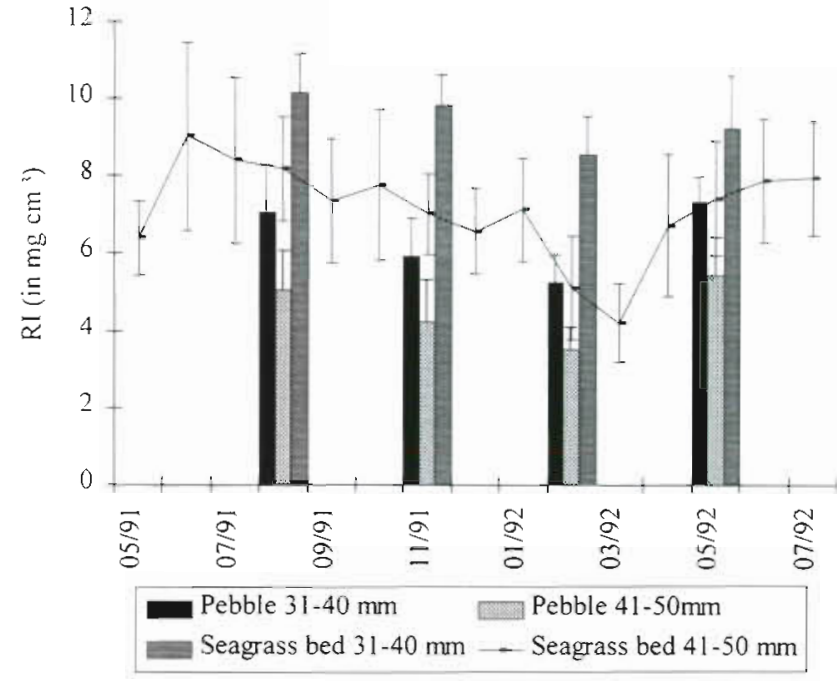

Fig. 4. Paracentrotus lividus. Impact of food availability on repletion index (RI). Monthly and quarterly measures of Rl tor 2 size classes of sea urchins living in seagrass bed and/or on pebble bottom

as a grazer and exhibits a specific food preference. choosing C. nodosa (Fernandez 1990). Conversely, sea urchins living on pebbles face limiting feeding conditions (plant resources are very low). The feeding pattern of $P$. lividus at this site is therefore that of a detritus feeder and browser, mainly consuming plant detritus (Fernandez 1990), which has a low nutritive value (Mazzella et al. 1992). In fact, the differences between the 2 stations are sharper than the repletion index suggests if we examine the organic matter really ingested. At the pebble station, approximately $53 \%$ of the gut content consists of mineral material not used by sea urchins; the plant fraction accounts for only $24 \%$ of the content. At the seagrass bed station, the mineral fraction is only $3 \%$, while plant matter represents $95 \%$ of the gut content (Fernandez 1990). The quantity of nutrients present in the gut destined for the physiological functioning of the sea urchin is therefore greater at the seagrass bed station than at the pebble station.

The repletion index also varies according to the size of the sea urchin (2-way ANOVA, size factor: $F=6.2$ to 15.3, p < 0.01) (Fig. 3). The sea urchins from the 41 to $50 \mathrm{~mm}$ size class have a lower repletion index than those from the 31 to $40 \mathrm{~mm}$ size class.

\section{Gonad index}

The dynamics of the gonad index at the seagrass bed station over the course of the annual cycle (monthly samples), studied for the 41 to $50 \mathrm{~mm}$ size class, show strong seasonal variations (Fig. 5; 1-way ANOVA, $F=$ 


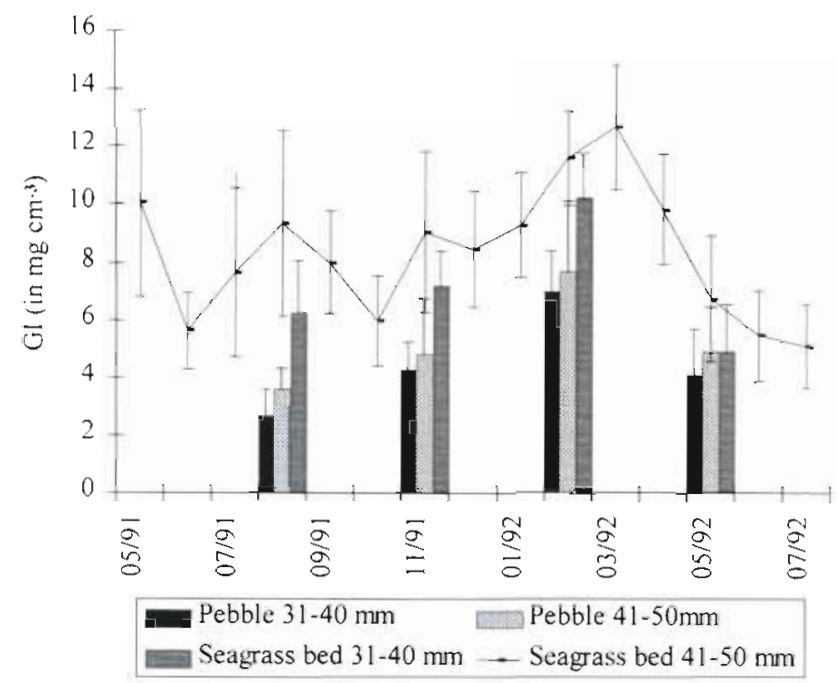

Fig. 5. Paracentrotus lividus. Impact of food availability on relative size of gonads. Monthly and quarterly measures of gonad index (Gl) for 2 size classes of sea urchins living in seagrass bed and/or on pebble bottom

9.7, $\mathrm{p}<0.001$ ). Statistical analysis shows significant drops in June 1991 and 1992 and in October 1991 (Tukey's HSD, p < 0.05). Two-way ANOVA results reveal that for the trimestrial samples, whatever the month of study (with the exception of the month of May 1992), the station factor has a significant effect (station factor: $F=10.5$ to $30.9, p<0.0001$ ). The mean gonad index of individuals from the seagrass bed station is significantly higher than that for the pebble station. The size factor also has a significant effect (size factor: $F=6.3$ to $12.7, \mathrm{p}<0.05$ ) with the gonad index being significantly lower for small individuals.

\section{Gut index}

The gut index presents a marked seasonal variation (1-way ANOVA, $F=21.5 ; \mathrm{p}<0.0001$; Fig. 6). Two-way ANOVA carried out on gut indices (Fig. 6) each month indicates that the size and station factors are not significant (station factor: $F=1.2$ to $3.8, \mathrm{p}>0.05$; size factor: $F=0.01$ to $4.02, \mathrm{p}>0.05$ ).

\section{Test index}

The test index does not vary significantly over the course of the year (1-way ANOVA, $F=1.5$ and $F=1.6$ respectively, $p>0.05$; Fig. 7). Analysis of results for the 2 sites (Fig. 7) shows a significant effect of the station factor but not of the size factor (2-way ANOVA, station factor $F=5.3$ to $61.6, \mathrm{p}<0.05$, size factor: $F=1.0$ to 3.6 , $p>0.05$ ). Sea urchins from the pebble station have a test index that is significantly lower than that of the seagrass bed station.

\section{Lantern index}

Seasonal variations of the lantern index are not significant (1-way ANOVA, $F=1.6, p>0.05$; Fig. 8). With regards to the results from the 2 stations (Fig. 8), 2-way ANOVA indicates that the station factor and the size

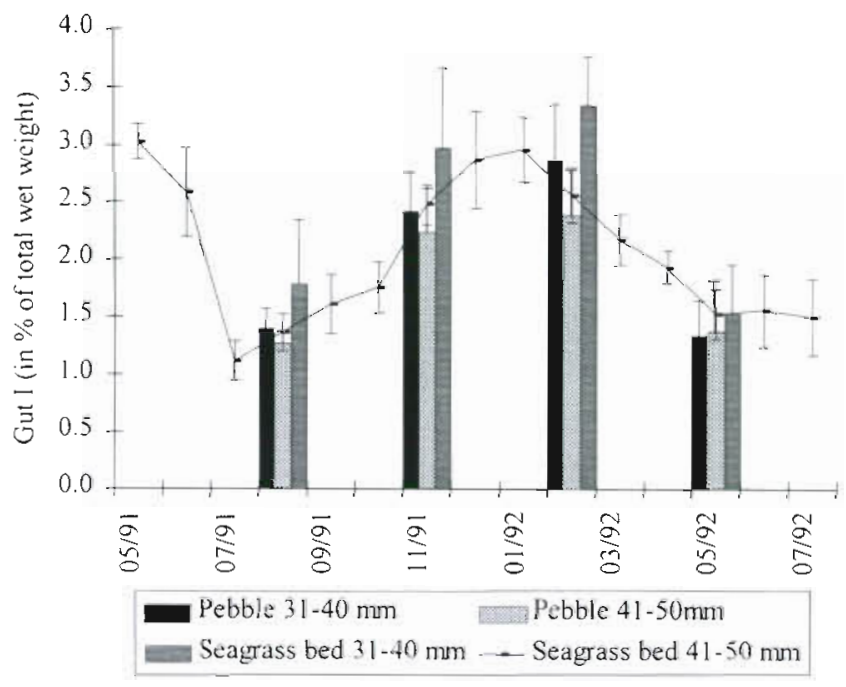

Fig. 6. Paracentrotus lividus. Impact of food availability on relative size of gut. Monthly and quarterly measures of gut index (Gut I) for 2 size classes of sea urchins living in seagrass bed and/or on pebble bottom

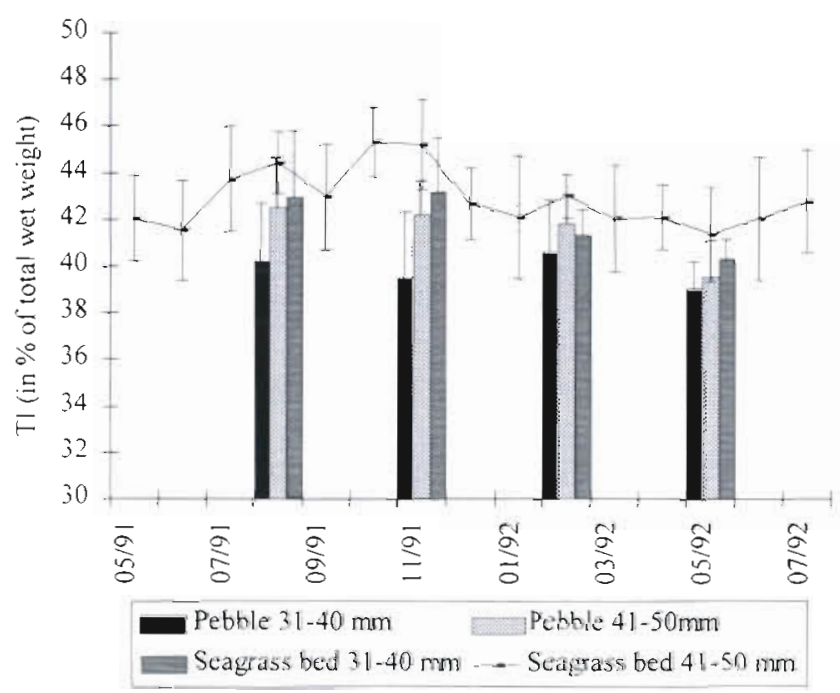

Fig. 7 Paracentrotus livdus. Impact of food availability on relative size of test. Monthly and quarterly measures of test index (TI) for 2 size classes of sea urchins living in seagrass bed and/or on pebble bottom 


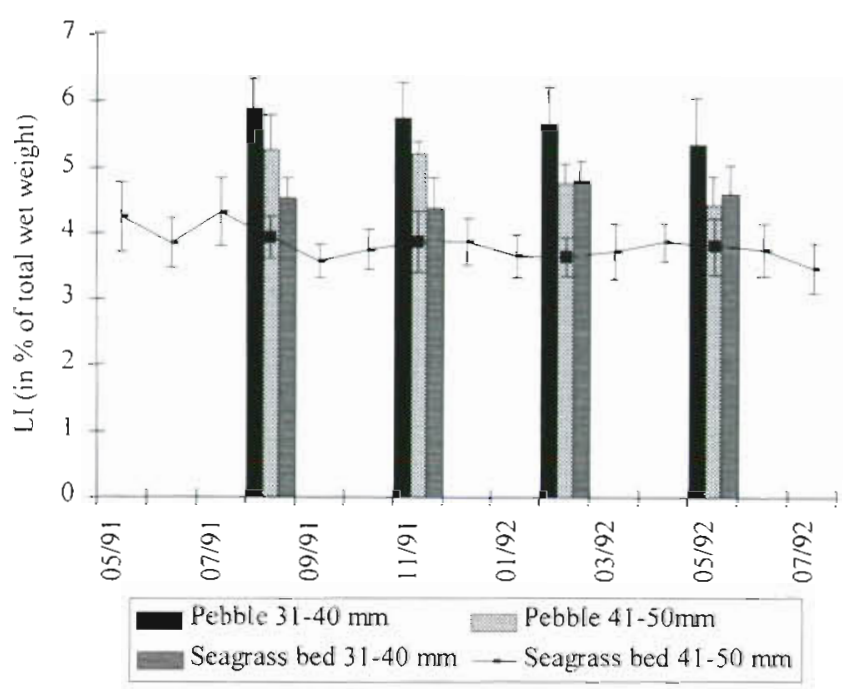

Fig. 8. Paracentrotus lividus. Impact of food availability on relative size of Aristotle's lantern. Monthly and quarterly measures of lantern index (LI) for 2 size classes of sea urchins living in seagrass bed and/or on pebble bottom

factor are both significant (station factor: $F=9.0$ to 55.0, $p<0.001$, size factor: $F=11.2$ to $38.8, p<0.001$ ). The lantern index is significantly higher for smaller individuals, and the sea urchins from the pebble station have a higher lantern index than those from the seagrass beds.

\section{DISCUSSION}

\section{Relative size of the gonads, gut, test and lantern}

The weight distributions of the different components of Paracentrotus lividus are similar overall to those observed for other Echinoidea species (Giese 1966, Lawrence 1967, Fenaux et al. 1977, Lawrence \& Byrne 1994), with nevertheless notable differences for some components. If one compares the distribution of components in the 2 sympatric species Arbacia lixula (Linnaeus) (Fenaux et al. 1977, Régis 1978) and $P$. lividus (these data), it is clear that $P$. lividus has relatively smaller tests and lanterns than $A$. lixula. These differences can be explained by the different environmental conditions in which the 2 species live. A. lixula lives on vertical or sub-vertical smooth walls (Harmelin et al. 1981), its power of adhesion is ensured by long spines (which contribute to the greater weight of the test in this species) (Régis 1978). In addition, the distribution of the sucker podia below the ambitus means that this sea urchin cannot resume its initial position if it is overturned (Boudouresque pers. obs.). The greater test weight can therefore con- tribute to improving the sea urchin's stability when exposed to hydrodynamic forces: it is an adaptive value. Moreover, an increase in the relative test weight contributes to an increased survivorship (Ebert 1982, 1988) In contrast, P. lividus lives more commonly in broken terrain. With its shorter spines and sucker podia all over the surface of the test, it can return to the normal position if it is overturned. Its hydrodynamic stability is therefore less crucial. The lighter test enables it to move around more easily on broken ground, and thus to have access to food resources present there. The development of the lantern is generally linked to the species feeding mode. A. lixula is a selective browser and feeds mainly on the encrusting and tufting phytobenthos with a preference for encrusting coralline algae (Frantzis et al. 1988). A large feeding apparatus therefore has an adaptive value. In contrast, $P$. lividus is a grazer that feeds mainly on the arborescent stratum (Nédélec 1982, Verlaque 1987, Frantzis et al. 1988). This stratum is made up of 'soft' algae and therefore does not necessitate a strong development of the lantern.

\section{Seasonal index variations}

Gonad, repletion and gut indices vary significantly with season. Fenaux et al. (1977; for Arbacia lixula) also noted that the test and the lantern indices do not show significant variations throughout the year. The drop in the gonad index during the study period (Fig. 5) is linked to the occurrence of spawning in the spring and late summer-early autumn. Spawning during these 2 periods has often been reported for Paracentrotus lividus in the Mediterranean (Fenaux 1968, Allain 1975, Régis 1979, Semroud 1993, but see also Lozano et al. 1995). Conversely, observations in the Atlantic have generally shown a single incidence of spawning in the summer (Byrne 1990). We ourselves observed, in the tanks of an experimental $P$. lividus rearing facility close to the study site, a mass spawning in October 1993 and a second in May 1994. Moreover, Verlaque (1984) observed, in Corsica, the appearance of $P$. lividus juveniles twice per year. This tends to confirm the occurrence of 2 spawning events for this species in this area of the Mediterranean.

The comparison between the variations in gonad and repletion indices reveals that the low repletion index values correspond to periods when the gonad index is at its highest level. Other authors have also observed, in Echinoidea, a low feeding rate when the gonads are highly developed (Lawrence 1987. Lumingas 1994, Lozano et al. 1995). Leighton (1968) suggests that this is probably due to the physical reduction of 
the space in the coelomic cavity when the gonads are highly developed. Moreover, when gametogenesis is over, food requirements may be reduced. Energy is then only required for maintenance and growth. Nevertheless, Régis (1979) has noted in Paracentrotus lividus from Marseilles (Mediterranean, France) that similar patterns of variation exist for the 2 indices.

The gut index drop observed in the winter-spring occurs before the drop in the gonad index. These results are consistent with those of Lawrence et al. (1965) and Fenaux et al. (1977). According to Fenaux et al. (1977), this decrease probably corresponds to a mobilisation of the nutrient reserves in the gut to provide biochemical constituents for gametogenesis. Conversely, Lawrence \& Lane (1982) suggest that these changes mainly reflect the change in nutritional conditions as gut index is dependent on the quantity of food ingested (Klinger et al. 1983). In the present study, it must be pointed out that this drop in the gut index occurs when the repletion index is at its annual minimum. These variations of the gut index could therefore be explained by a lower ingestion coupled with the utilisation of reserves for gametogenesis.

\section{Effect of size on morphological indices}

The size of the sea urchin affects the gonad, repletion, and lantern indices. The effect on the gonad index has been observed in other Echinoidea (Fuji 1967. Gonor 1972, Nichols et al. 1985, Pearse \& Cameron 1991, Semroud 1993, Lumingas 1994, Lozano et al. 1995). As a general rule, the relationship between the relative weight of the gonads and the size of individuals presents a positive slope (Fuji 1967, Gonor 1972, Lumingas 1994). Our results confirm this. This observation may nevertheless be strongly influenced by environmental conditions (Lumingas 1994). The differences observed for the repletion index are consistent with the conclusions of a number of authors who have shown that the relative rate of consumption of sea urchins decreases with size (Fuji 1967, Klinger 1982 Nédélec 1982, Semroud 1993, Lumingas 1994). The reasons for this correlation are poorly understood, but it is possible that it may be due to a decline in the capacity of individuals to acquire food and/or to a decrease in metabolic demand (Lumingas 1994). These metabolic adaptations may be explained by the fact that the greater the size of the sea urchins, the lower the growth rate; the food requirement may therefore be less. For the gut index, in contrast to the results of Moss \& Lawrence (1972) for Mellita quinquiesperforata (Leske) or of Ebert (1988), we did not observe differences between the 2 size classes. The size classes that were used here are perhaps too close to each other to give rise to significant differences. Certain authors have observed a decreasing allometry between the test weight and the diameter (or total weight of the animal) (Giese 1967, Ebert 1982, 1988, Lumingas 1994). Our findings do not confirm these results. This change of relative test weight could also be accompanied by a change in skeletal architecture: regular echinoids become higher at the apex as size increases (Telford 1985).

As in the case of the gut index, it is possible that our size classes are too close to be able to identify differences. On the other hand, our results are identical to those of Régis (1978), who observed a constant test index for individuals regardless of size. Finally, a decrease in the relative weight of the lantern in relation to the total size is reported by Fuji (1967), Giese (1967), Régis (1978), Ebert (1988) and Lumingas (1994). Other organs related to the feeding function, such as the spines and podia, show similar variations (Lawrence 1987). As we have noted for the repletion index, the relative diminution of the food acquisition organ with size might be explained by a drop in the energy requirement for large sized specimens. Since the growth of large sea urchins is low or nil, the sea urchin's energy needs are limited to maintenance and reproduction. The development of food acquisition organs may therefore no longer be a priority.

\section{Phenotypic plasticity as a function of resource availability}

The availability of food is very different at the 2 stations, which has repercussions on food availability in the gut for the different physiological functions. It is known that differences in the quantity and quality of food have a significant effect on gonad growth (Fuji 1967, Lawrence \& Lane 1982, Keats et al. 1984) even for populations located only a short distance from one another (Vadas 1977, Byrne 1990, Lumingas 1994, see also Lozano et al. 1995). Generally, feeding on 'preferred' species induces greater gonad growth than feeding on 'avoided' species (Vadas 1977, Larson et al. 1980). The high gonad index observed in the seagrass bed may therefore be partly due not only to the abundance of the food but also to its quality: Cymodocea nodosa is indeed considered a 'preferred' food source by Paracentrotus lividus (Traer 1980). Some authors have also shown that the population density has an impact on gonad growth: despite similar feeding patterns, gonad indices are higher when the population density is low (Andrew 1986, Guettaf \& San Martin 1995). At the 2 sampling stations, the population density is very different. The low gonad indices observed in pebble areas can therefore also be attributed to the 
high density observed. If our gonad index values are compared with data in the literature (for $P$. lividus greater than $35 \mathrm{~mm}$ in size), it should be noted that, regardless of the station, the lagoonal sea urchin gonad index is always higher than that of sea urchins taken in open sea (Semroud 1993. Fernandez et al. 1995, Guettaf \& San Martin 1995). The fact that gonad indices are higher in coastal lagoons has already been reported (Azzolina 1988). Conversely, Lozano et al. (1995) pointed out that the gonad index of an unstable population (with elevated hydrodynamics, the proximity of a river mouth and highly fluctuating environmental conditions) of $P$. lividus was higher than that of a stable population (with low hydrodynamics, no direct discharge from a river mouth and low fluctuating environmental conditions). These authors explain this phenomenon by the fact that the unstable population probably devoted more energy to reproduction. It should bo noted that lagoonal environments, such ds the one of the present study, are characterised by variable environmental conditions (temperature, salinity, oxygen, etc.).

Among the various parameters that have a significant impact on the test morphology in different populations of the same species, the most important seem to be the hydrodynamic conditions and the available food resources (Moore 1935, Giese 1967, Dix 1970, Lumingas 1994). In our study, hydrodynamic forces at the 2 stations are very low and are assumed not to play a significant role. With regard to food resources, several authors have demonstrated that there is a positive relationship between the abundance of food and the thickness of the test (and thus its weight) (Dix 1970, Lumingas 1994). Régis (1978) noted a different relationship between food and test weight. While this author recorded a lower relative test weight (without the spines) at a station where the macroscopic food supply was low, the relative weight of the spines was high. The length of the spines apparently increases to enable the sea urchin to make the best use of dissolved trophic resources by tegumentary absorption (Régis 1978). Our results tend to confirm those of Dix (1970) and Lumingas (1994). At the station where food is abundant, the animals' tests (with spines) are heavier. A heavier test (greater mass) can increase the chances of survival (Ebert 1982, 1988). This increase in the thickness of the test could help the sea urchin escape fish predation, which could be important in a Paracentrotus lividus population (Sala 1992). The sea urchins living at the seagrass bed station may therefore, thanks to the abundance of trophic resources, increase the relative weight of their tests and thus increase their longevity.

As for the test, for sea urchins, the lantern is an organ whose morphology can vary as a function of resources availability. Some authors have shown that limited resources may give rise to an increase in lantern size (Ebert 1980, Black et al. 1982, Lumingas 1994). In individuals living on pebble bottoms, the size of the feeding apparatus therefore appears to increase in size to enable the organism to collect the scarce food present in this biotope more efficiently. On the other hand, the abundance of food in the seagrass beds means that sea urchins living in this biotope can devote fewer resources to the lantern and more to other organs such as the test or the gonads. Finally, the gut is an important organ for stocking reserves in the Echinoidea (Lawrence et al. 1965, Fenaux et al. 1977). In light of this, it would seem reasonable that this index be higher at the seagrass bed station where trophic resources are abundant. Klinger et al. (1983) and Lawrence (1987), for Lytechinus variegatus (Lamarck) and Echinometra mathaei (de Blanville), also observed that the abundance of food had no impact on the relative size of the gut.

It would therefore appear that phenotypic variations can be observed in populations which are not totally isolated from each other. Indeed, no physical barrier exists to limit migration between ine 2 viotopes. The migration of individuals from the pebble zone to the seagrass bed has, in fact, already been observed (Fernandez 1990) and similar migrations between populations of a lagoon have also been observed elsewhere (Kitching \& Ebling 1961, Kitching \& Thain 1983). Experiments involving the transfer of sea urchins from the pebble zone to enclosures within the seagrass bed (and fed Cymodocea nodosa in excess) have been carried out. The results of these experiments reveal that morphological modifications occur quite rapidly (in $12 \mathrm{mo}$ ) and result in an increase in relative test and gonad weight and a decrease in lantern index (Fernandez 1996). The organism's plasticity therefore allows a rapid change in its morphology.

\section{Conclusions}

The population of Paracentrotus lividus living in the seagrass beds of the Urbinu lagoon seems to present an annual reproduction cycle with a spring and an autumnal spawn. This cycle would appear to be identical to that already observed for this species in the open sea in this part of the Mediterranean. The repletion index shows minor fluctuations over the course of the year with, nevertheless, a strong decline in late winter when the gonad index is at its maximum. The gut index follows the fluctuations of the gonad index but with a time lag: it decreases at the end of the gonads' maturation, during the period when the repletion index is at its minimum. The test and lantern indices do not present seasonal variations. 
The size of the individual has a significant impact on the gonad, repletion, and lantern indices. The gonad index increases with sea urchin size while, conversely, the repletion and lantern indices decrease. These differences can be attributed to energy allocation being dependent on the size (and, presumably, the age) of individuals.

Finally, there are marked differences in the physiological indices between the 2 sampling stations: there is a morphometrical response to environmental conditions. This response seems to be mainly due to the quantity and quality of available food. Sea urchins that live in the seagrass beds (where food resources are preferred and not limiting) have a higher gonad, repletion and test index than specimens that live in pebble zones (where the food resources are low). Conversely, the lantern index is highest for individuals living on pebble bottoms. When food is abundant (in the seagrass bed), Paracentrotus lividus presents a higher reproductive potential, ingestion rate and test weight which could help the sea urchin escape predation. When food is limiting, the somatic and reproductive activities decrease and the feeding apparatus is developed to maximise food acquisition. These variations are due to the energy allocation which differs with food resource availability. Depending on the available food quality and quantity, energy is distributed differently to the 3 components which are maintenance, growth and reproduction. $P$. lividus is therefore capable of changing depending on its available food resources; a strategy that has impacts at both the physiological and morphometrical levels. This demonstrates the phenoptypic plasticity of this species.

Acknowledgements. The authors thank R. J. Rowley, X. Turon and J. M. Lawrence for their comments on an earlier draft of this manuscript and 3 anonymous referees for valuable criticism. We thank also L. Bronzini of Caraffa, manager of the SCORSA for allowing us to work in the Urbinu lagoon and for making available facilities at sea. We also thank Prof. D. Viale, of the Universite de Corse, for the interest that she has shown in our research.

\section{LITERATURE CITED}

Allain JY (1975) Structure des population de Paracentrotus lividus (Lmk) (Echinodermata, Echinoidea) soumise à la pêche sur les côtes Nord Bretagne. Rev Trav Inst Pèches Marit 39(2):171-212

Andrew NL (1986) The interaction between diet and density in influencing reproductive output in the echinoid Evechinus chloroticus (Val.). J Exp Mar Biol Ecol 97:63-79

Azzolina JF (1988) Contribution à l'étude de la dynamique des populations de l'oursin comestible Paracentrotus lividus (Lamarck). Croissance, recrutement, mortalité, migrations. PhD thesis, Univ Aix-Marseille II

Black R, Johnson MS, Trendal JT (1982) Relative size of Aristotle's lantern in Echinometra mathaei occurring at different densities. Mar Biol 71:101-106
Byrne M (1990) Annual reproductive cycles of the commercial sea urchin Paracentrotus lividus from an exposed intertidal and a sheltered subtidal habitat on the west coast of Ireland. Mar Biol 104:275-289

Delmas G, Regis MB (1984) Influence d'une pollution complexe à dominante domestique sur les populations de l'echinoide comestible Paracentrotus lividus (Lamarck). Vie Mar 6:63-72

Dix TG (1970) Biology of Evechinus chloroticus from different localities. 2. Movement. NZ J Mar Freshwat Res 4(3): $267-277$

Ebert TA (1980) Relative growth of sea urchin jaws: an example of plastic resource allocation. Bull Mar Sci 30:467-474

Ebert TA (1982) Longevity, life history, and relative body wall size in sea urchins. Ecol Monogr 45:353-394

Ebert TA (1988) Allometry, design and constraint of body components and of shape in sea urchins. J Nat Hist 22: $1407-1425$

Ebert TA (1996) Adaptative aspects of phenotypic plasticity in echinoderms. Oceanol Acta 19(3-4):347-355

Edwards PB, Ebert TA (1991) Plastic responses to limited food availability and spine damage in the sea urchin Strongylocentrotus purpuratus (Stimpson). J Exp Mar Biol Ecol 145: $205-220$

Fenaux L (1968) Maturation des gonades et cycle saisonnier des larves chez Arbacia lixula (L.), Paracentrotus lividus et Psammechinus microtuberculatus (Echinides) à Villefranche-sur-Mer. Vie Milieu 19:1-52

Fenaux L, Malara G, Cellario C, Charra R, Palazzoli I (1977) Evolution des constituants biochimiques des principaux compartiments de l'oursin Arbacia lixula (L.) au cours d'un cycle sexuel et des effets d'un jeune de courte durée au cours de la maturation sexuelle. J Exp Mar Biol Ecol 28: $17-30$

Fernandez C (1990) Recherches préliminaires à la mise en place d'un pilote d'aquaculture de l'oursin Paracentrotus lividus dans un étang corse. Mém DEA Océanologie, Univ Aix-Marseille II

Fernandez C (1996) Croissance et nutrition de Paracentrotus lividus dans le cadre d'un projet aquacole avec alimentation artificielle. PhD thesis, Univ Corse

Fernandez C, Dombrowski E, Caltagirone A. (1995) Gonadic growth of adult sea urchin Paracentrotus lividus (Echinodermata: Echinoidea) in rearing: the effect of different diet type. In: Emson R, Smith A, Campbell A (eds) Echinoderm research 1995. AA Balkema, Rotterdam, p 269-275

Frantzis A, Berthon JF, Maggiore F (1988) Relation trophique entre les oursin Arbacia lixula et Paracentrotus lividus (Echinoïdea regularia) et le phytobenthos infralittoral superficiel de la baie de Port-Cros (Var, France). Sci Rep Port-Cros Natl Park 14:81-140

Fuji A (1967) Ecological studies on the growth and food consumption of Japanese common littoral sed urchin Strongylocentrotus intermedius (Agassiz). Mem Fac Fish Hokkaido Univ 15 (2):83-160

Giese AC (1966) On the biochemical constitution of some Echinoderms. In: Boolotian RA (ed) Physiologie of Echinodermata. Academic Press, New York, p 757-796

Giese AC (1967) Changes in body-component indexes and respiration with size in the purple sea urchin Strongylocentrotus purpuratus. Physiol Zool 40:194-200

Gonor JJ (1972) Gonad growth in the sea urchin Strongylocentrotus purpuratus (Stimpson) (Echinodermata: Echinoidea) and the assumption of gonad index method. J Exp Mar Biol Ecol 10:89-103

Guettaf M, San Martin GA (1995) Etude de la variabilité de l'indice gonadique de l'oursin comestible Paracentrotus 
lividus (Echinodermata: Echinidae) en Méditerranée Nord-occidentale. Vie Milieu 45(2):129-137

Harmelin JG, Bouchon C, Hong JS (1981) Impact de la pollutıon sur la distribution des échinodermes des substrats durs en Provence (Méditerranée Nord Occidentale). Téthys 10(1):13-36

Keats DW, Steele DH, South. GR (1984) Depth-dependent reproductive outup of the green sea urchin, Strongylocentrotus droebachiensis (O.F. Müller), in relation to the nature and availability of food. J Exp Mar Biol Ecol 80: $77-91$

Kitchıng JA, Ebling FJ (1961) The ecology of Lough Ine XI. The control of algae by Paracentrotus lividus (Echinoidea). J Anim Ecol 30(2):373-383

Kitching JA, Thain VM (1983) The ecological impact of the sea-urchin Paracentrotus lividus in L. Ine, Ireland. Philos Trans R Soc Lon Ser B Biol Sci 300:513-532

Klinger TS (1982) Feeding rate of Lytechinus variegatus Lamarck (Echinodermata: Echinoidea) on differing physiognomies of an artificial food of uniform composition. In: Lawrence JM (ed) International Echinoderms conference. AA Balkema, Rotterdam, p 29-32

Klinger TS, Mc Carthy BM, Lawrence Jivi (1983) The effect of food quantity and quality upon somatic and gonadal growth of Lytechinus variegatus Lamarck (Echinodermata: Echinordea). Am Zool 23:964

Larson BR, Vadas RL, Keser M (1980) Feeding and nutritional ecology of the sea urchin Strongylocentrotus druebachiensis in Maine. Mar Biol 59:49-62

Lawrence JM (1967) Lipid reserves in the gut of three species of tropical sea urchins. Carib J Sci $7(1-2): 65-68$

Lawrence JM (1987) A functional biology of Echinoderms. In: Calow P (ed) Functional biology series. Croom Helm Ltd, Beckenham

Lawrence JM, Byrne M (1994) Allocation of resources to body components in Heliocidaris erythrogramma and Heliocidaris tuberculata (Echinodermata: Echinoidea). Zool Sci 11:133-137

Lawrence JM, Lane JM (1982) The utilisation of nutrients by post metamorphic echinoderms. In: Jangoux M, Lawrence JM (eds) Echinoderm nutrition. AA Balkema, Rotterdam, p 331-371

Lawrence JM, Lawrence AL, Holland ND (1965) Annual cycle in the size of the gut of the purple sea urchin, Strongylocentrotus purpuratus (Stimpson). Nature 205:1238-1239

Leighton DL (1968) A comparative study of food selection. and nutrition in the abalone Haliotis rufescens (Swainson) and the sea urchin Strongylocentrotus purpuratus (Stimpson). PhD thesis, Univ California, San Diego

Lozano J, Galera J, Lopez S. Turon X, Palacın C, Morera G (1995) Biological cycles and recruitment of Paracentrotus lividus (Echinodermata: Echinoidea) in 2 contrasting habltats. Mar Ecol Prog Ser 122:179-191

Lumnigas LJL (1994) La plasticité chez l'oursin Sphaerechinus granularis en rade de Brest (Bretagne, France). PhD thesis, Univ Bretagne Occidentale

Mazzella L, Buia M, Gambi MC, Lorenti M, Russo GF, Scipione MB, Zupo V (1992) Plant-animal trophic relationships in the Posidonia oceanica ecosystem of the Mediterranean sea: a review. In: John DM, Hawkins SJ, Prince JH (eds) Plant-animal. interactions in the marine benthos. Clarendon Press, Oxford, p 165-188

Moore HB (1935) A comparison of the biology of Echinus

This article was submitted to the editor esculentus in different habitats. Part II. J Mar Biol Assoc UK 20.109-128

Moss JE, Lawrence JM (1972) Changes in carbohydrates, lipids and protein levels with age and season in the sand dollar Mellita quinquiesperforata. J Exp Mar Biol Ecol 8: 225-239

Nédélec H (1982) Ethologie alimentaire de Paracentrotus lividus dans la baie de Galena (Corse) et son impact sur le peuplement phytobenthique. PhD thesis, Univ P. M. Curie and Univ Aix-Marseille II

Nédélec $H$ (1983) Sur un nouvel indice de réplétion pour les oursins réguliers. Rapp PV Réun Comm Int Explor Sci Mer Médit Monaco 28(3):149-151

Nichols D, Bishop GM, Sime AAT (1985) Reproductive and nutritional periodicities in populations of European sea urchin Echinus esculentus (Echinodermata: Echinoidea) from the English Channel. J Mar Biol Assoc UK 65: $203-220$

Pearse JS, Cameron RA (1991) Echinodermata Echinoidea. In: Giese A, Pearse JS, Pearse VB (eds) Reproduction of marine invertebrates, Vol VI, Echinoderms and Locophophorates. The Boxwood Press, California, p 513-662

Regis MB (1.478) Croissance de deux echinoides du golfc de Marseille (Paracentrotus lividus (Lmk) et Arbacia lixula L.). Aspects écologiques de la microstructure du squelette et de l'evolution des indices physiologiques. PhD thesis, Univ Alx-Marseille III

Régis MiB (1979) Analyse des tluctuations des indices physiologiques chez deux Echinoides (Paracentrotus lividus (Lmk) et Arbacia lixula (L.)) du golfe de Marseille. Téthys $9(2): 167-181$

Sala E (1992) The role of fishes in the organization of a Mediterranean sublittoral community. PhD thesis, Univ Aix-Marseille II

Semroud R (1993) Contributıon à la connaissance de l'écosystème à Posidonia oceanica (L.) Delile dans la région d'Alger (Algérie): étude de quelques compartiments. PhD thesis, Univ Sciences et Technol (USTHB), Algiers

Telford $M$ (1985) Domes, arches and urchins: the skeletal architecture of echinoids (Echinodermata). Zoomorphology 105:114-124

Traer K (1980) The consumption of Posidonia oceanica Delile by echinoids at the Isle of Ischia. In: Jangoux $M$ (ed) Echinoderms: present and past. AA Balkema, Rotterdam, p 241-244

Turon X, Gibiret G, Lopez S, Palacin C (1995) Growth and population structure of Paracentrotus lividus (Echinodermata: Echinoidea) in 2 contrasting habitats. Mar Ecol Prog Ser 122:193-20

Vadas RL (1977) Preferential feeding: an optimization strategy in sea urchins. Ecol Monogr 47:337-371

Verlaque $M$ (1984) Bılogie des juvéniles de l'oursin herbivore Paracentrotus lividus (Lamarck): sélectivité du broutage et impact de l'espèce sur les communautés algales de substrat rocheux en Corse (Méditerranée, France). Botanica Mar 27(9):401-424

Verlaque M (1987) Relations entre Paracentrotus lividus (Lmk) et le phytobenthos de Méditerranée occidentale. In: Boudouresque CF (ed) Colloque international sur Paracentrotus lividus et les oursins comestibles. GIS Posidone, Marseille, p 5-36

Zar JH (1984) Biostatistical analysis. Prentice-Hall International, Englewood Cliffs, NJ

Manuscript first received: December 2, 1996

Revised version accepted: March 12, 1997 